\title{
Kingdom, church and civil society: A theological paradigm for civil action
}

Author:
J. (Koos) M. Vorster ${ }^{1}$
Affiliation:
'Faculty of Theology,
North-West University,
Potchefstroom Campus,
South Africa
Correspondence to:
J. (Koos) M. Vorster
Email:
koos.vorster@nwu.ac.za
Postal address:
03 Goedehoop Street,
Potchefstroom 2531,
South Africa
Dates:
Received: 05 Sept. 2014
Accepted: 12 Feb. 2015
Published: 23 Apr. 2015
How to cite this article:
Vorster, J., 2015, 'Kingdom,
church and civil society: A
theological paradigm for
civil action', HTS Teologiese
Studies/Theological Studies
71(3), Art. \#2816, 7 pages.
http://dx.doi.org/10.4102/
hts.v71i3.2816
Copyright:
@ 2015. The Authors.
Licensee: AOSIS
OpenJournals. This work is
licensed under the Creative
Commons Attribution
License.

\section{Read online:}

This article deals with the role that churches can and should play in civil society to develop societal morally. The central-theoretical argument is that the biblical notion of the kingdom of God can, when it is systematically and theologically developed, offer an acceptable foundation for the civil action of churches. In light of this the article takes a new look at the neo-Calvinist view on church and society. The kingdom implies the life encompassing governance of God, the formation of the church and the creation of a moral sense amongst people. The church can, from the perspective of the kingdom, be seen as a community within which Christians should be equipped for social action. The church is a power station which carries forth the light of the Gospel by means of the social involvement of believers in civil society. Christians can, based on natural law, work with civil organisations to pursue the common good of the community. Such collaboration becomes possible only when civil society works purpose- and not paradigm-driven. Based on the moral sense that is founded in natural law, Christians can be socially active within civil society in search of the greatest benefit for all people within the community.

\section{Introduction}

The role of civil society in the development of the South African society has increasingly been receiving attention over the past 20 years. This new interest is because of the growing belief in South Africa that the development of the nation and core virtues such as peace, reconciliation, transformation and hope, cannot be left to the political discourse alone. After 20 years of democracy, guided by a government with a clear and strong mandate from the electorate, the political discourse and application of new policies did not lead to the delivery of the initial promise of a healthy society. In spite of many laudable attempts by the five administrations since 1994, the society suffers under the burdens of poverty, corruption, inequality, poor service delivery and labour unrest (cf. the studies of Terreblanche 2003, 2014; Dassah 2008; Webb 2009). Hence the growing interest in the possibilities civil society can offer in the development of a healthy and a moral society.

In the past, with a few exceptions such as the vigorous campaign of the United Democratic Front (UDF) against the system of apartheid in the 1980s, civil society in South Africa was not utilised to a great extent to change or influence the course of political and social events. This stagnant situation changed in 1994 when the new democratic constitution, based on neo-liberal constitutionalism came into being and South Africa moved from the apartheid system to a full democracy. ${ }^{1}$ The new democracy provided the freedom and the space for civil society to enter the social discourse in an unimpeded way. Soon the vacuum was filled with several civil organisations such as trade unions, health organisations and associations of people striving to promote a certain cause. However, the role of churches in this regard is still ambiguous. This is as a result of the discord amongst churches during the time of apartheid, where the theological support of the government by some churches and the struggle of other churches against apartheid resulted in a general suspicion in society about the role churches should play in the social domain. ${ }^{2}$ It seems that churches are now rather embracing evangelicalism and have thus retreated into the safe space of nurturing worship, diaconate, evangelism and spirituality, resorting to an absence in the public sphere.

1.The new constitution not only makes provision for freedom of association and the right to protest, but instituted viable mechanisms that can be utilised for the purpose of extra political social critique. The Constitutional Court was established to protect the citizenry from the abuse of power by the government and this court has since been utilised for this purpose in a highly efficient way (Republic of South Africa 1996). 2.The Church struggle in South Africa is thoroughly described by De Gruchy (2005). He indicates how churches in South Africa
during the time of apartheid were engrossed in a vigorous discourse on the role of churches in politics and how this discourse during the time of apartheid were engrossed in a vigorous discourse on the role of churches in politics and how this discourse
led to much confusion in society, especially amongst Christians. In a recent study Olivier (2011:66) indicates that churches in the post-1994 society tend to retreat to a quietist mode and become hesitant to be involved in social criticism due to the struggle of the past. In this way churches are not part of solutions, but 'part of the problem' in the process of community development and nation-building. 
The quietism of South African churches regarding the social and political discourse can, to my mind, be ascribed to the lack of a well-defined theological paradigm for cooperation with civil society and inclusive social action. In spite of a rich tradition in this regard, a new evangelical inclination in the South African ecclesiological domain inhibits Christians and churches from entering the space that the new constitutional dispensation opens up for civil action. This presentation attempts to define a theological paradigm for ecclesiastical involvement in civil action in cooperation with civil society. The central-theoretical argument is that a theology of the kingdom of God and the reign of Christ can lay the foundation for sound and effective civil action by churches and Christians in cooperation with secular civil societies and other religions. This argument will draw on the reformed tradition as it developed in South Africa over the years, as well as the applicable insights of modern day theologians. The topics under discussion will be the characteristics of the kingdom of God, the church as the people of the kingdom and the kingdom and civil society and civil action.

\section{The characteristics of the kingdom of God}

The theology of the kingdom of God has become an important paradigm in recent reformed theological research in South Africa. This development is evident in many local publications in ethics, missiology, ecclesiology and practical theology. ${ }^{3}$ This research departs from the notion that the concept of the kingdom can be regarded as one of the central issues in the biblical revelation. This point of departure is founded on the study of Bright. In his well-known book on the topic in 1963, Bright (1973:7) goes as far as to say: 'For the kingdom of God is in a real sense the total message of the Bible'. Although this statement is open to criticism it nevertheless indicates at least how fundamental the idea of the kingdom of God is in the history of salvation and biblical theology.

The phrase 'kingdom of God' does not occur in the Old Testament, but the substance to which it refers is clearly visible. It becomes visible in the continuous preaching of the reign of God and in his intention to renew creation through redemption in Christ and regeneration by the Holy Spirit (Du Toit 1969b:11-13; Vriezen 1966:146; Welker 2013:211). The idea of the constant reign of God in communion with people constitutes the unity of the theology of the Old Testament. The idea of the reign of God is also a basic message of the New Testament (Van der Walt 1962:37). In the New Testament several different expressions can be found describing the kingdom of God. These are: kingdom of heaven (Mt 3; 2; 4:17; 5:19; 18:1, 4); kingdom of God (Mt 6:33; Lk 12:31; Mk 1:14);

3.This development was due to the influence of theologians such as Kuyper and Bavinck and the Calvinistic philosophy that was developed in the Netherlands. This in turn influenced the Reformed thinking in the United States and other parts of the in turn influenced the Reformed thinking in the United States and other parts of th world where this theology took root. See for example Bright (1973) and BeasleyMurray (1987). The interest in research about the concept kingdom of God in the South African theological discourse was inspired by the well-known publication of the Dutch New Testament scholar Ridderbos (1950). Two other publication furthered and applied his research in South Africa. These are Van der Walt (1962) and Du Toit (1969a). Heyns (1977) also developed his influential ecclesiology within the framework of this paradigm. kingdom of Christ (Lk 22:30; Col 1:13); kingdom of God and of Christ (Eph 5:5); kingdom (1 Cor 15:24; Ja 2:5; Rv 1:9) and kingdom of the Father (Mt 13:43; 26:29; Lk 12:32).

All of these expressions are attempts to explain the reign of the Triune God. Therefore, one can conclude that the concept 'reign of God' can be looked upon as the first and foremost characteristic of the biblical idea of the kingdom of God. As said earlier, the Old Testament proclaims the reality of the reign of God over the whole of creation (Vriezen 1966). The New Testament proclaims the reign of God as it becomes manifest in the coming of Christ and the formation of the people of God (Beasley-Murray 1987:20; Guthrie 1981:419; Ridderbos 1950:47; Van der Walt 1962:32). The reign of God is both a present and a future reality. Küng (1992:56) calls this a futurist-presentist eschatology (see also the discussion of Ladd 1961:25 \& Welker 2013:209). This reign has already been manifested in principle in the coming, life, suffering, death and resurrection of Christ, but it will only be revealed in its completeness in the new heaven and earth. The whole biblical history of the covenant is an indication of the historical reality of the kingdom. Some of the teachings of Jesus point to the kingdom as a present reality, and others to the kingdom as a future reality. However, these expressions are not contradictory. Conzelmann (1976:114) argues persuasively that the two have the same significance for human existence.

The term presentist-futurist eschatology was actually used by Küng as a description of the reign of God, which erupts into the present, takes on power in the present and is fulfilled and completed in Jesus. Moltmann (1965:22) did not use this terminology, but he entertained the same idea. He maintains that Christianity stands and falls with the reality of Jesus' resurrection from the dead by God and his vindication over the powers of this earth. With this event the kingdom of God became a new reality in world history. But it will reach its completeness in the future. It is at the same time a reality and a promise. It is here (present) but will reach its fulfilment with the end of human history (see also Ridderbos 1950). Moltmann (2012:37) argues that eschatology should therefore be defined as a transformative eschatology and that the present reign of God cuts deep into the ills of society. He contends that salvation of the kingdom, because of the presentist reign of God, takes effect in the struggle for economic justice, human dignity, solidarity against the alienation of human beings and the struggle for hope against despair in individual life.

The reign of God as a present reality, finds concrete expression in the coming and teaching of Christ. Welker (2013:209) deals with this issue in depth. He indicates that through Jesus Christ and the power of the divine spirit, God's reign reveals the loving, preserving, salvific and uplifting activity of the Creator and the Triune God. Over and against the notion of understanding God's revelation in Christ in the power of the spirit from the perspective of 'Creation' and 'Creator', he posits that the resurrected and exalted Christ is not present apart from the Holy Spirit and that it is through the divine spirit that he includes his witness 
in his post-easter life. The reign of Christ is executed in his threefold office or the threefold gestalt of the reign of Christ or the threefold gestalt of the reign of God. ${ }^{4}$ This threefold gestalt of the reign of Christ generates the power of the spirit, the formation of the church and Christian action in public life. The threefold office of Christ thus constitutes the organic relationship between the reign in concrete realistic terms in the public sphere (Welker 2013:247). ${ }^{5}$

The kingdom is thus a kingdom with a unique moral nature and quality. This unique moral character is determined by the law of the kingdom that is written on the heart of every human being. Calvin (Institutes 2:7:1) reiterated the reality of the moral conscience given to all people as a result of God's general goodness. This moral conscience can be described as moral or natural law. Witte (2007:59) summarised Calvin's various expressions of the natural law as follows: 'Calvin used a variety of terms to describe this moral law such as: 'the voice of nature'; 'the engraven law'; 'the law of nature'; 'the natural law'; 'the inner mind'; 'the rule of equity'; 'the natural sense'; 'the sense of divine judgement'; 'the testimony of the heart'; 'the inner voice' amongst other terms. This idea became a prominent feature in the post-reformation discourse on the idea of the two kingdoms and natural law. ${ }^{6}$

The moral quality of the kingdom can be summarised in the words of the great commandment. It is a kingdom of love in the widest sense of the word. This quality is like a diamond with many facets which are, amongst others, the love of God and fellow human beings, reconciliation, justice, transformation of the discriminatory society, upliftment of the poor and the destitute, hope and peace. It is indeed, in the words of Hauerwas (1983), a peaceable kingdom. The reign of God becomes visible where love vindicates hatred and enmity and where people are reconciled over and above all the social divisions caused by humankind's inclination to prejudice. These are the qualities that should be pursued by the people of the kingdom. Highly important in the manifestation of the present reign of God according to the 4.Welker prefers to speak of the 'threefold office' rather than the 'three offices of
Christ' because the offices interpenetrate each other and are thus perichoretically connected.

5.Welker notes: 'Christ's royal office or the royal gestalt of God's reign both inside and outside of churches exhibits an unstoppable dynamic; a grand current of what individually are often quite inconspicuous deeds of free, creative self-withdrawal, love, acceptance, loving concern, and forgiveness sets into motion enormous emergent processes and developments' (Welker 2013:247).

6.Although Calvin did not present a complete and extensive treatise on the idea of natural law, his ideas about natural law and its implications for ethics, the philosophy of law and the development of democracy and constitutional law were produced by Vermigli, Zanchi, Turretin and Althusius. The idea of natural law became a highly contentious issue in Reformed Theology in the 20th century due became a highly contentious issue in Reformed Theology in the 20th century due to the negative and disastrous influences of natural theology in ideologies such as
national-socialism in Germany and apartheid in South Africa. The debate about Calvin's view on natural law reached its apex in the 1934 debate between Barth and Brunner. Barth (1992:360) campaigned for a 'divine command ethics' over and against an ethics based on natural law and creation theology (see Brunner \& Barth 1946). Over and against the fierce critique of Barth against any notion of natural law, Brunner pointed out that this idea is part and parcel of the Reformed tradition. In a recent study Grabill (2006) explains the re-emergence of the idea of natural law in reformed ethics after a time where this idea, which was prominent natural law in refor in the social thought of the reformers and their immediate predecessors, declined due to the Barthian position. Grabill points out that the antithetic ethical stance of reformed ethics, as proposed by Barth and some of his contemporaries, is makin way for a rediscovery of natural law, which enables Christians to cooperate with other moral agents in the pursuance of universal moral directives. A thorough and informative information about Calvin's influence in this regard are also provided by Witte (2007:143) and Van Drunen $(2010,2014)$. threefold office of Christ is the formation of the church. This topic will be elucidated in the next section.

\section{The people of the kingdom of God}

A further characteristic of the kingdom of God is the community that results from the work of Christ, namely the church. The time between the promise and initial irruption of the kingdom and the final fulfilment of the promise is a Zwischenraum where the church is sent into the world to proclaim the message of hope. This going out into the world: '... is a going out of those who no longer adhere to the sinful structures of the world' (Harvie 2009:31). The church lives eschatologically in its message of hope and as God's sanctified people. To accomplish this God-given task, the people of God have received the spirit and the gifts of the spirit. The motivating force in the quest of hope is the Christian love as the foundation of all gifts of the spirit.

The church can therefore be regarded as a present sign of the kingdom (Heyns 1977:23). The church is the universal community of believers. However, this universal community manifests itself in the local congregation (Lindijer 1962:54; Küng 1992:224; Snyman 1977:25). We can distinguish between the universal church that comprises all the believers all over the world and the local church that comprises the believers of a certain place. The New Testament speaks of the church as a worldwide 'body of Christ', but also of the church as a local congregation, for example the church of Jerusalem, Ephesus and Antioch. The church is the 'working terrain' of the spirit although the word of the spirit cannot be limited to the church alone.

The spirit-filled local congregation also bears all the attributes of the universal church. It is ecclesia completa. It has the same responsibility, namely to embody the reign of God according to the threefold office of Christ and everything it represents, such as love, hope, peace, joy, servant hood and stewardship. In addition to being the sign of the kingdom, the church is also the 'spear point' of the kingdom. The church should embody, reveal and promote the reign of God in the world. Therefore the essence and calling of the church must be defined within the broader concept of the kingdom. The church is subservient to the kingdom, and this determines every aspect of church life.

The relation of kingdom and church is essential to an understanding of both concepts. The kingdom is all about the establishment, recognition and eventual vindication of the reign of God. The church is a visible sign of this reign, but also its herald. The word servanthood thus captures the essential role of the church. The church as a congregation of believers, as well as individual Christians are servants in service of the kingdom of God. Bonhoeffer (1995:61) called attention to this concept in the troubled situation of World War II, and his ethics of servanthood are still very relevant. Servant hood manifests itself as stewardship, one of the characteristics of a Christian attitude. Stackhouse (1995:26) reminds us that stewardship is a major guideline in Christian 
moral action. Thus, the church as the universal church, as well as the established congregations of believers at a local level, comprising all believers at a certain time, are servants in the kingdom of God. Like Christ, they also have the threefold office to execute in the social spheres. The kingdom is coming with its principles such as justice, love, joy, peace, forgiveness and reconciliation. The kingdom changes reality. Therefore the servant of the kingdom must be involved in the furthering of these noble principles in order to change society. The church will inevitably also be a servant in the world - an instrument of change.

How should this calling be carried into effect? In this respect I would like to revisit the ecclesiology of neo-Calvinism as it was modified over the last century in this tradition. The ecclesiology of the Dutch theologian Kuyper (1892:134) dominated reformed thinking about the church and its calling in this tradition for many decades, especially after the turmoil of two World Wars and the necessity of a new vision of the task of the churches and Christians in a post-war society. ${ }^{7}$ His distinction between the visible and the invisible church is well-known. In the early stages of his theological reflection he said that the invisible church comprises all the believers of all times as well as worldwide. The visible church is an institution for the ministry of the Word and sacrament and has no broader task. The institute has no social function and cannot be seen as a civil society. At a later stage Kuyper (1909:205) still distinguished between the visible and invisible church. The invisible church is the body of Christ as it is unseen in history and in the contemporary world. It is the mysterious body of Christ over the centuries and latent in nations and cultures. He founded this opinion on the Westminster Confession (Kuyper 1943:61). The visible church has two modes of existence, namely the church as institute and the church as organism (Kuyper 1909:204). The institute is the officially organised congregation of believers with the sole task of the ministry of the Word and sacraments. This official institutionalised church has no other function in society. The instituted church is sovereign in its own circle, and is one societal sphere amongst others such as marriage, family, and other forms of social organisations. In terms of the topic under discussion this view would entail that the instituted church has no function in civil society.

However, according to Kuyper, the church is also an organism and this term describes the presence of Christians in all spheres of civil society, such as political parties, trade unions and business corporations, and in government institutions. The institute is there solely for the ministry of Word and sacraments, but the organism is present in the society to proclaim the reign of Christ and to promote

7.The ecclesiology of neo-Calvinism became popular in reformed circles in the Netherlands, North America and South Africa and had a huge influence on the Netherlands, North America and South Africa and had a huge influence on the limitation of the social role of Reformed Churches. In South Africa the quietism of churches of the Dutch Reformed tradition regarding apartheid can be ascribed to this ecclesiology. Churches in this tradition refrained from criticising the policies of the government and claimed that the church should not be involved in politic because such an involvement will lead to the deformation of the church. For Kuyper's influence in North America see Van Drunen (2010:349). His influence in South Africa is adequately described by De Gruchy (2005). the morality of the kingdom in all spheres of society. Kuyper was of the opinion that Christians should establish Christian civil organisations to fulfil this task. As a result of his ecclesiology the Dutch society was for a long time the example of the existence of all kinds of Christian civil organisations which aimed to further the cause of Christian morality in the civil sphere. The ecclesiology of Kuyper also resonated strongly in the neo-Calvinist philosophy of the idea of law of the philosopher Dooyeweerd. Dooyeweerd (1933:481) describes the church as institute as a communion with an own unique destiny. It should function besides other civil societies as a body that is sovereign in its own circle. However, it has no civil function, for its calling is limited to the ministry of the Word and the sacraments. Over and against that, Christian civil societies should promote the morality of the kingdom, but should not transgress onto each other's domains. When the church as institute transgresses onto the terrain of civil society, it is a sign of deformation of the church. This view of the role of the church limited the task of the instituted church to the pursuance of spirituality in a pietistic sense.

The ecclesiology of neo-Calvinist theology and philosophy met with strong criticism in South Africa during the latter part of the 20th century because of its limitation of the function of the instituted church in society amidst huge social challenges. Because of influences from theologians such as Barth, Moltmann, Hauerwas and Bosch, the viewpoint of the social role of the instituted church was reconsidered. Barth (1946:33) describes the relation between church and society (state) as an analogical relation. The light of the reign of Christ falls on the church and the church should reflect this light by way of the preaching of the Word to the state. On the other hand, Moltmann defines the Christian community as a moral agent that should not conform to the world, nor flee from it, but should change the plight of the suffering in an active way. ${ }^{8}$ Hauerwas $(1981: 72,1983: 99)$ became known for his dictum that the church does not have a social ethic, but is a social ethic and should radiate the principles of Christian morality to society by way of its own moral stance. The church should not bring an alternative story, but should be the alternative story to be told (Hauerwas 2001:150). Bosch (1991:172) describes the church as an alternative community that should set the example to society by being in itself a harmonised, loving, peaceful, transformed and reconciled community. These views present valuable insights from different theological paradigms. But the question remains: how could these views be converted into a viable and workable plan of action for the church in civil society in South Africa today?

In view of the insights mentioned above I choose a model that can be described by the metaphor of the instituted church as an 'electric power plant'. The metaphor was introduced by Duvenage $(1962,1970: 206)$ in a thesis about the relation between church and nation in South Africa.

8.Moltmann (2012:40) develops his ecclesiology within his theology of hope and his view is explained anew in his Ethics of Hope. 
I venture to develop this metaphor further in view of core elements of the ecclesiology of neo-Calvinism, but also those of Barth, Moltmann, Hauerwas and Bosch. As Hauerwas and Bosch contend, the instituted church should be an exemplary community. It should act as a civil society by setting the example of a reconciled, loving and peace-seeking community. Society at large should see in the congregation a model of love, fairness, justice and sound morality. Furthermore, the church as part of civil society should act as a moral agent by testifying to the noble principles of the kingdom, as Barth and Moltmann remind us. By acting as such the instituted church acts like an 'electric power plant' that generates the energy for social action. The life of the church, the worship, preaching, diaconate and the prophetic witness of the church must be focused on the development of awareness, values, knowledge, willingness and abilities of individual Christians.

However, this metaphor contains an additional important element. An electric power plant generates power, but the power is transmitted to a city by way of electric cables that are connected to all parts of a region or a city in order to produce light and energy where it is needed. Applied to the church as an electric power plant this metaphor entails that Christians, equipped by the instituted church, can be described as the 'cables' that bring light and energy to society. In the instituted church the 'energy' is generated by worship and the ministry of the Word and the sacraments. Christians as the 'cables' of the 'electric power plant' should then relay this energy to society by way of social action according to the moral principles flowing from the reign of Christ as expressed in the Word and the sacraments. The instituted church should thus be an empowering community where Christians are equipped and trained to be active in society. To summarise: the church should be an example of a high moral standard; should testify about the moral implications of the reign of Christ, but, more importantly, should be a community where Christians are equipped to fulfil their calling as moral agents in society.

\section{The kingdom and civil society}

The African Medical and Research Foundation and Dalberg Global Development Advisors (2013) define a Civil Society Organisation (CSO) as an association of people that exists to promote economic and social development. Normally speaking, a CSO would be non-profit, non-governmental and non-partisan (i.e. non-party political). Such a definition would include faith based groups, trade unions, nongovernmental organisations, village associations, producer groups, professional associations, universities and the like, big and small. From this broad definition, it can be seen that a CSO refers to all actors who are not connected to the state or private sector for profit motivated players, with a social mission as an essential part of the definition of a CSO. This definition is useful for the purposes of this research on the condition that social development should be defined in its broadest sense to also include issues such as cultural, educational and spiritual development.
Civil societies can be paradigm driven or purpose driven. In their exposition of the relation kingdom, church and civil society Kuyper (1909:204) and Dooyeweerd (1933:451) made a case for paradigm driven civil societies emanating from a reformed view of society. Based on their respective ecclesiologies they propagated the formation of all kinds of Christian societies, such as Christian universities, political parties, media, trade unions and all other kinds of Christian organisations. In their view these organisations can also be regarded as the manifestation of the ecclesia visilibis and each of them are sovereign in its own circle. The root of this line of thought is the notion of the basic antithesis between Christian and non-Christian paradigms, and even between Christian traditions mutually. Their views resulted in the 'pillarization' of the Dutch society. All kinds of Christian organisations were established alongside other civil societies. This practice was to a lesser extent also followed in reformed circles in North America and South Africa.

It is difficult to measure the effect of civil societies in such a 'pillarized' community. However, I would like to raise certain concerns in this respect such as:

- Is antithesis really the message and meaning of the reign of Christ?

- Are the values derived from the reign of Christ exclusive to Christians alone, or can they be translated to broad social values to the benefit of the whole community of people?

- Is the message and deeper meaning of reconciliation as the renewal of all relationships not compromised and limited by such a Christian paradigm-driven approach?

- How effective is such an exclusive approach in a society plagued by injustice and divisions?

To my mind these questions require another approach, which I will define as a purpose driven approach.

The purpose driven approach entails that people of all religions and persuasions form a civil organisation to attain a certain goal. The purpose usually is a common goal which civil societies want to attain and they organise themselves and their actions in view of the common goal. The common goal determines their co-operation and united actions. Good examples of such an approach are the United Democratic Front (UDF) in the South African struggle against apartheid and the Treatment Action Campaign (TAC) in the struggle for governmental involvement in the treatment of HIV and Aids. ${ }^{9}$ The UDF appeared in the midst of this social atmosphere as a civil organisation that aimed to promote human rights and challenge the apartheid government. The organisation moved outside parliamentary politics and by way of all kinds of non-violent protest actions promoted the establishment of an inclusive democracy for the whole of the population. The UDF was established in 1983 with the intent to unite several civil organisations into a united front against apartheid and the government of the day (South African

9.The history of the civil action of the UDF and the TAC has been discussed at length in another article (see Vorster in press). 
History Online [SAHO] 2014:1). It quickly became a platform from which Christian leaders and church organisations made their voices heard against the one-dimensional South African society of the apartheid securocracy (Walshe 1997:393). In the area of economics the organisation protested the capitalism of apartheid (Terreblanche 2002:85). This was carried out in cooperation with trade unions, student and many other organisations in the secular realm. In spite of ideological differences between the member organisations, the UDF acted as a united front with the purpose of dismantling apartheid, and played a major role in the political transition in South Africa.

Another example of this purpose-driven approach is the TAC. The increasing HIV and Aids crisis in South Africa and the unwillingness of the Mbeki government to introduce programmes to curb the spread of the disease led to the establishment of the TAC (Heywood 2010:139). This civil organisation was founded on 10 December 1998 with the aim of changing government policy to make antiretroviral drugs more accessible, initially with the help of the government (Dubula \& Heywood 2011:1). The support base of this organisation included community-based organisations, churches and other religious institutions, labour organisations, unions and individuals within political parties (Grawitsky 2002:54). The alliance that the organisation formed with the labour movement 'Congress of South African Trade Unions' (COSATU) early on is of special significance. Initially, the mission of the TAC was to mobilise support for the government in its fight against pharmaceutical companies which generated large profits from anti-retroviral drugs. This support had positive results early on, but with the growth of Mbeki's denial of the true causes of Aids because of his distrust of the medical research in this regard, the TAC's support changed to opposition. The TAC developed into a large civil movement that exerted pressure on the government to change its negative policy and to provide anti-retroviral drugs to infected persons.

Grawitsky (2002:53) compares the TAC with the UDF of the 1980s. The difference is that the UDF wanted to overthrow the government of the day, whilst the TAC, in comparison, wanted to change government policy in an extra-parliamentary way. The TAC wanted to convince the government in a peaceful manner to alter their views and policies. However, the government regarded the activities of the TAC with suspicion, even antagonism. The organisation therefore had to take more drastic action. This short summary of the article by Vorster (in press) is to prove that purpose driven organisations provide ample opportunity for Christians to be deeply involved in problem solving actions of civil society. In this way Christians, equipped by the church, can proclaim the moral standards of the reign of Christ by way of civil action.

The purpose driven approach can be guided by the principle of the common good and the possibility of a global ethics. Küng (1997:93) has developed the idea of the prospect of a global ethic for modern politics and economics in a plausible way. Both Christians and people of other faiths, beliefs and convictions can participate in actions aimed at serving the common good of society. The Christian idea of natural law provides a sound foundation for a global ethic as a foundation for cooperation in civil action. ${ }^{10}$ As said before, the law of God is engraved on the hearts of all people, described in the written Word of God and summarised in the Decalogue. As a moral guide to every human being the engraven law (natural law) spells out the common good which can be pursued by everyone.

Rawls (1999:7) entertains the same idea in his description of a well-ordered society and provides a useful directive for a purpose driven approach. He argues that a well-ordered society is stable when it is relatively homogeneous in its basic moral beliefs. However, in a pluralistic society the application of this hypothesis is problematic because modern democratic societies are characterised by a multitude of incompatible and irreconcilable doctrines that are religious, philosophical and moral in nature. Although Rawls does not deal with civil society in this respect, one can derive from his point of view that this problem can also occur in civil societies that are paradigm driven. To solve the problem in a democratic society, Rawls (1993:134) proposes the idea of overlapping consensus. In his view a well-ordered society needs an overlapping consensus that allows for a plurality of reasonable, although opposing, comprehensive doctrines, each with its own conceptions of the good (Vorster 2010:595). A well-ordered society can be stable when a political concept of justice can be offered that all supporters of a reasonable doctrine can endorse from their own philosophical, ideological or moral point of view. Applied to civil society this overlapping consensus entails that the purpose driven civil society can find common ground on the common good for a certain cause. The purpose driven civil society can function on the basis of an overlapping consensus on moral directives that can drive civil action.

\section{Conclusion}

The biblical concept of the kingdom of God offers a feasible theological paradigm for constructive civil action by churches and Christians as part of civil society. This paradigm enables Christians and churches to partake as transmitters of the morality of the reign of Christ into society. This can be achieved by purpose driven civil action on the basis of overlapping consensus about the common good of society. Such action can be constructive by enhancing the moral directives of the reign of Christ such as human dignity, nation building, peace-making, liberation, reconciliation, transformation and hope.

10.In a recent study Grabill (2006) explains the re-emergence of the idea of natural law in reformed ethics after a time where this idea, which was prominent in the social thought of the reformers and their immediate predecessors, declined due to social thought of the reformers and their immediate predecessors, declined due to the Barthian position as revealed in the 1934 debate between Barth and Brunner. Barth (1992:360) campaigned for a 'divine command ethics' over and against an ethics based on natural law and creation theology (see Brunner \& Barth 1946). Grabill points out that the antithetic ethical stance of reformed ethics, as proposed by Barth and some of his contemporaries, is making way for a rediscovery of natural law, which enables Christians to cooperate with other moral agents in the pursuance of universal moral directives. 


\section{Acknowledgements Competing interests}

The author declares that he has no financial or personal relationships which may have inappropriately influenced him in writing this article.

\section{References}

African Medical and Research Foundation and Dalberg Global Development Advisors, 2013, Contribution of civil society organisations to health in Africa, AMREF, Nairobi.

Barth, K., 1946, Christgemeinde und Burgergemeinde, Evangelische Verlag, Zurich.

Barth, K., 1992, Church dogmatics, The doctrine of reconciliation, vol. iv.i, T \& T Clark Edinburgh.

Beasley-Murray, G.R., 1987, Jesus and the Kingdom of God, Eerdmans, Grand Rapids. Bonhoeffer, D., 1995, Ethics, Touchstone, London.

Bosch, D.J., 1991, Transforming mission: Paradigm shifts in the theology of mission, Mary Knoll, New York.

Bright, J., 1973, The Kingdom of God, Abingdon Press, New York.

Brunner, E. \& Barth, K., 1946, Natural theology, Geoffrey Bles, London.

Calvin, J. 2008, Institutes of the Christian religion, Hendriksen, Peabody.

Conzelmann, H., 1976, An outline of the theology of the Old Testament, SCM Press, London.

Dassah, M.O., 2008, 'Is there a hole in the bucket? Identifying drivers of public secto corruption, effects and instituting effective combative measures', Journal of Public Administration 43(3.1), 37-62.

De Gruchy, J.W., 2005, The church struggle in South Africa, Fortress Press, Philadelphia. Dooyeweerd, H., 1933, De wijsbegeerte der wetsidee, vol. 3, Kok, Kampen.

Du Toit, S. (ed.), 1969a, Die koninkryk van God, Potchefstroom Herald, Potchefstroom.

Du Toit, S., 1969b, 'Die koninkryk van God in die Ou Testament', in S. Du Toit (ed.), Die koninkryk van God, pp. 11-13, Potchefstroom Herald, Potchefstroom.

Dubula, V. \& Heywood, M., 2011, 'A decade of fighting for our lives', UN Chronicle $48(1), 30-31$.

Duvenage, S.C.W., 1962, Kerk, volk en jeug: Die verhouding van kerk tot volk, J. Heijnis, Zaandijk.

Duvenage, S.C.W., 1970, 'Die geïnstitueerde kerk en die Suid-Afrikaanse volkskultuur', Koers 37(3/4), 206-218. http://dx.doi.org/10.4102/koers.v37i3/4.1321

Grabill, S.J., 2006, Rediscovering the natural law in reformed theological ethics, Eerdmans, Grand Rapids.

Gravitsky, R., 2002, 'How the TAC is emerging as a social movement', Health and Safety 26(4), 53-55.

Guthrie, D., 1981, New Testament theology, Inter-Varsity Press, Leicester.

Harvie, T., 2009, Jürgen Moltmann's ethics of hope: Eschatological possibilities for moral action, Ashgate, Surrey.

Hauerwas, S., 1981, A community of character toward a constructive Christian social ethic, Notre Dame Press, Notre Dame.

Hauerwas, S., 1983, The peaceable kingdom: A primar in Christian Ethics, University of Notre Dame, Notre Dame.

Hauerwas, S., 2001, 'The church as God's new language', in The Hauerwas reader, Duke University Press, Durham and London. http://dx.doi. org/10.1215/9780822380368-010

Heyns, J.A., 1977, Die Kerk, NG Kerkboekhandel, Pretoria.
Heywood, M., 2010, 'Civil society and uncivil government', in D. Glaser (ed.), Mbek and after: Reflections on the legacy of Thabo Mbeki, pp. 128-162, Wits University and after: Reflections

Küng, H., 1992, The church, Burns and Oates, Kent.

Küng, H., 1997, 'A global ethic for global politics and economics', SCM Press, London. Kuyper, A., 1892, E Voto Dordraceno, vol. 2, Kok, Kampen.

Kuyper, A., 1909, Encyclopedie der heilige Godgeleerdheid, vol. 3, Kok, Kampen.

Kuyper, A., 1943, Calvinism: Six stone foundation lectures, Eerdmans, Grand Rapids. Ladd, G.E., 1961, The Gospel of the Kingdom of God, Eerdmans Grand Rapids. Lindijer, C.H., 1962, Kerk en koninkrijk, Ten Have, Amsterdam.

Moltmann, J., 1965, Theologie der Hoffnung, Untersuchungen und Begründung und zu den Konsequenzen einer christlichen Eschatologie, Chr. Kaiser Verlag, Munich.

Moltmann, J., 2012, Ethics of hope, SCM Press, London.

Olivier, E., 2011, 'Violence: The church is part of the problem', Verbum et Ecclesia 32(2), 66-70. http://dx.doi.org/10.4102/ve.v32i2.510

Rawls, J., 1993, Political liberalism, Columbia University Press, New York.

Rawls, J., 1999, A theory of justice, Harvard University Press, Cambridge, Mass.

Republic of South Africa, 1996, Constitution of the Republic of South Africa, Government Printer, Pretoria.

Ridderbos, H., 1950, De komst van het koninkrijk: Jezus' prediking volgens de synoptische evangeliën, Kok, Kampen.

Snyman, W.J., 1977, Nuwe en ou dinge: Uit die skat van die koninkryk, Pro Rege, Potchefstroom.

South African History Online (SAHO), United Democratic Front, viewed 14 April 2014 from http://www.sahistory.org.za/organisations/united-democratic-front-udf

Stackhouse, M.L., 1995, 'Christian social ethics in a global era: Reforming Protestant views', Christian social ethics in a global era, Abingdon, Nashville.

Terreblanche, S., 2002, A history of inequality in South Africa 1652-2002, University of Natal Press, Pietermaritzburg.

Terreblanche, S., 2003, A history of inequality in South Africa 1652-2002, University of Natal Press, Pietermaritzburg.

Terreblanche, S., 2014, Verdeelde land: Hoe oorgang in Suid-Afrika faal, Tafelberg, Cape Town.

Van der Walt, T., 1962, Die koninkryk van God-naby!, Kok, Kampen.

Van Drunen, D., 2010, Natural law and the two kingdoms. A study in the development of Reformed social thought, Eerdmans, Grand Rapids.

Van Drunen, D., 2014, Divine covenants and moral order: A biblical theology of natural law, Eerdmans, Grand Rapids.

Vorster, J.M. (in press), 'The possible contribution of civil society in the moral edification of South African society: The example of the "United Democratic Front" and the "Treatment Action Campaign" (1983-2014)', HTS Theological Front" and
Studies.

Vorster, N., 2010, 'Are freedom and equality natural enemies? A Christian-Theological perspective', The Heythrop Journal, A Bimonthly Review of Philosophy and Theology 51(4), 594-609. http://dx.doi.org/10.1111/j.1468-2265.2010.00576.x

Vriezen, T.C., 1966, Hoofdlijnen der theologie van het Oude Testament, Veenman en Zonen, Wageningen.

Walshe, P., 1997, 'Christianity and the anti-apartheid struggle: The prophetic voice within divided churches', in R. Elphick \& R. Davenport (eds.), Christianity in South Africa. A political, social and cultural history, pp. 383-399, David Philip, Cape Town.

Webb, W., 2009, 'Prevention is better than cure: Promoting public service integrity', SA Crime Quarterly 27(3), 7-13.

Welker, M., 2013, God the revealed: Christology, Eerdmans, Grand Rapids.

Witte, J. (Jnr), 2007, The reformation of rights: Law, religion, and human rights in early modern Calvinism, Cambridge University Press, Cambridge. 